\title{
SLC45A3 wt Allele
}

National Cancer Institute

\section{Source}

National Cancer Institute. SLC45A3 wt Allele. NCI Thesaurus. Code C97792.

Human SLC45A3 wild-type allele is located in the vicinity of $1 \mathrm{q} 32.1$ and is approximately $23 \mathrm{~kb}$ in length. This allele, which encodes solute carrier family 45 member 3 protein, is involved in the modulation of transport. A chromosomal translocation of this gene and the BRAF gene is associated with prostate cancer. 